\title{
NEW WORLD
}

\section{All Change af the Top}

\section{from our Washington Staff}

Dr Lee DuBridge, Science Adviser to the President for the past few years, startled the establishment last Thursday with the announcement of his resignation from the end of August. He will be succeeded by Dr Edward E. David, a computer engineer from the Bell Telephone Laboratories. Dr DuBridge's departure from the White House will be accompanied by other important changes. At the National Science Foundation, the post of deputy director has at last been filled, again by an engineer-Professor Raymond L. Bisplinghoff, dean of the school of engineering at MIT. In the past few days it has become known that the successor to Representative Emilio Q. Daddario, chairman of the Subcommittee on Science, Research and Development, in the House of Representatives, will be Mr John W. Davies, the most senior of the six Democrats on the subcommittee.

The departure of Dr DuBridge will have the most immediate effect. He said last week that he had always had "a horror of staying at any job past reasonable retirement age". There is no doubt of the affection with which he is held in Washington, where he has been highly respected. It is also widely appreciated that the best time in which to be Science Adviser to the President is when expenditure on research and development is growing quickly, for then there is a good chance that the extra funds will be supposed to have been conjured up by the Science Adviser himself. From this point of view, Dr DuBridge has been unlucky, but his spell in office has also been marred by the muddle over the effects of the Mansfield Amendment on the pattern of federal research expenditure-effects that could have been anticipated. At the end of last week, Senator Mansfield went out of his way to emphasise that he had no personal quarrel with Dr DuBridge on this score.

Dr David is a Bell Labs man to the core. He moved there from MIT in 1950 and worked for more than a decade on underwater acoustics. Since then he has been engaged on computing science and has also played an important part in developing the high school curriculum intended to introduce young people to a sense of the importance of technology.

The appointment of Professor Bisplinghoff as deputy director of the NSF also raises new problems, for the post that he will occupy was only created two years ago and has not previously been filled. In an attempt to strengthen the foundation's hand in the Administration, Congress argued that it should have a deputy director and four assistant directors all of them appointed by the President. The four assistant directors are already at work (see Nature, 226, 105; 1970) and no doubt the deputy director would also by now have been at work for some time if the first choice for the post, Professor George Hammond, of the California Institute of Technology, had not blotted his copybook in June by speaking out against the Cambodian operation. There remains, however, some confusion about the precise function of the men now serving as assistants and deputy directors. With the National Science Board brooding over the foundation's work, does it really need six highly paid administrators to spend a mere $\$ 500$ million?

Dr Bisplinghoff has a NASA background, having been associate administrator for advanced research and technology from 1963 to 1965 and special assistant to the then administrator, Mr James Webb, for a further two years. More recently, Dr Bisplinghoff has been the chairman of a working party intended to advise the Administration on supersonic air transports. $\mathrm{He}$ is known to take the line that the SST would be a fine thing if its noise could be kept within bounds.

In the long run, the appointment of Representative Davies as chairman of the subcommittee on Science, Research and Development may turn out to be the most important of all the changes. $\mathrm{Mr}$ Daddario has for several years exercised a powerful influence on science policy, chiefly by making himself one of the few people

\section{No Budgef Yet}

THE National Science Foundation is one of several agencies whose budgets for the current year have been snatched away by the President's veto on August 11 of the independent offices. On the same date, President Nixon also vetoed appropriations for the Office of Education. Both bills between them included roughly $\$ 1,000$ million for work not originally spelled out in the Administration's budget- $\$ 453$ million extra for education and $\$ 451$ million extra for the independent agencies. Although the National Science Foundation stood to gain $\$ 9.6$ million above the Administration's request for $\$ 513$ million, what seems to have stuck in the Administration's throat is the extra $\$ 300$ million appropriated by Congress for urban development. The next step will be for Congress to devise a more acceptable bill and there is a chance that this will find its way through Congress in the next few weeks. 
in Congress who understood what the Administration was doing. Towards the end of his reign--Mr Daddario is almost certain to be elected governor of Connecticut in November--he has been influential enough to develop the legislation within which the NSF now operates. In the past few months, Mr Daddario has also lent his enthusiasm to doubtful projects such as that for setting up in Congress what he calls an Office for 'Technology Assessment.

Representative Davies is known to share Mr Daddario's enthusiasm for a stronger National Science Foundation. $\mathrm{He}$ is an amateur astronomer and holds a pilot's licence. His succession will not finally be assured until after the election in November, although there seems no doubt that he will be returned by his district in Georgia.

\section{CBW}

\section{Geneva Protocol at Last}

Withrn hours of the scuttling of the old Liberty ship LeBaron Russell Briggs with more than 10,000 disused nerve gas rockets on board, President Nixon last Thursday sent to Congress his proposal that the Geneva Protocol on the use of chemical and biological weapons should be ratified. This step has been on the cards for the best part of nine months, ever since the Administration conceded that the case for including these materials in the arsenals of the twentieth century had become irrelevant. By all accounts, the delay has been brought about partly by the need to work out a policy on the use of tear gases and defoliants, materials used not merely as agents for the restoration of civil order but also as military weapons of a kind, as in Vietnam. The compromise which seems now to have been arrived at is that the United States Government has accompanied support for the Geneva Protocol with a declaration that tear gases (especially CS gas) and defoliants will be excluded from the provisions of the protocol, but that these materials will not be used without express permission from the White House after the ending of the Vietnam War. It remains to be seen whether those in Congress who are asking for a prohibition of the use of military appropriations for chemical defoliants will be able to dislodge this carefully calculated position.

The Geneva Protocol, which prohibits the "use in war" of chemical and bacteriological weapons, was first negotiated within the League of Nations in 1925 and has been ratified by 85 nations. The unwillingness of the United States to ratify the declaration has always been regarded as one of its more obvious defects. The President's message to Congress last week reserves for the United States the right to use chemical weapons if these should be used in war by either an ally or an adversary. Similar reservations have been made by many of the other nations which have ratified the protocol, the Soviet Union, the United Kingdom and France included. On the other hand, the recommendation by the Administration to Congress goes further than the position of many of the other countries which have ratified the protocol in suggesting that bacteriological weapons will never be used, whatever other countries may do. In an accompanying document, Secretary of State Rogers also makes it clear that the
United States Government considers that toxins. however manufactured, will be considered as biological weapons and not chemical weapons. In this and other ways, the position of the United States on chemical and biological weapons has now been transformed within the short space of a year. Controversy remain: about the use of chemical agents in Vietnam, but the fact that the new position seems to have been reached after a hard-headed appraisal of the military inutilit $y^{-}$ of these materials as weapons is not considered a disgrace.

\section{SUPERSONIC TRANSPORT}

\section{Senator Proxmire Takes off}

The Subcommittee on Economy in Government, in the person of Senator William Proxmire, last week launched an attack on supersonic aircraft, Anglo-French and American alike, so carefully contrived to prevent them reaching commercial service that it may have the effect of rallying support in their favour. One of the weaknesses of Senator Proxmire's position is that his subcommittee's report on the supersonic aircraft project has already been repudiated by two of the nine members-Senators John Sparkman and Stuart Symington. Another is that the witnesses who gave evidence at the hearings on which the report was based were notable for the absence of staunch defenders of the SST. (Officials of the Boeing Company, now building the supersonic prototypes, declined to appear.) In a dissenting statement accompanying the Proxmire report, one member of the subcommittee, Representative Clarence J. Brown, says that "if the joint Economic Committee had been advising Queen Isabella, we would still be in Barcelona waiting to prove the world round before daring the Atlantic".

The effectiveness of Senator Proxmire's attack on the SST project should be known in the next few weeks, when the Senate is due finally to vote on the proposal to include $\$ 290$ million for the development of prototypes in the budget appropriation for the Department of Transportation. There seems very little doubt that the vote this year will be closer than in the past. In the past few weeks, there have also been signs that the Administration is more ambivalent than ever about the virtues of the SST, chiefly because of the difficulty of estimating the effects of supersonic aircraft on the environment. In circumstances like these, external developments could have an important influence on the United States programme--if the performance of the Concorde in its impending series of trials should turn out to be far below specification, for example, Congress would probably decide to save $\$ 290$ million.

The subcommittee's case against the SST is that the social costs outweigh the potential benefits of supersonic civil aircraft, that the project is neither sufficiently radical to carry the technology of flight further forward nor so prestigious as to add to the international reputation of the United States, and that the Anglo-French Concorde project is not a serious commercial threat to the United States aircraft industry.

There has been a steady stream of argument in the past few years about the effect of the SST project on the United States economy, internally and externally. The Proxmire subcommittee now comes out firmly with the view that the effect of the project on the level of 